\title{
Modelisasi komunikasi konstitutif Dewan Kehormatan Penyelenggara Pemilu periode 2012-2017 berdasarkan manajemen pengetahuan
}

\author{
Henni Gusfa ${ }^{1}$, Elly Yuliawati ${ }^{2}$, dan Irmawanti ${ }^{3}$ \\ ${ }_{1,2}^{1}$ Universitas Mercu Buana, Jakarta, Indonesia \\ ${ }^{3}$ Dewan Kehormatan Penyelenggara Pemilu, Jakarta, Indonesia
}

\begin{abstract}
ABSTRAK
DKPP adalah lembaga yang bertugas menangani pelanggaran kode etik penyelenggara pemilu dan merupakan satu kesatuan fungsi penyelenggaraan pemilu. Meskipun demikian, dalam menjalankan tugas dan kewenangannya DKPP menghadapi berbagai tantangan, diantaranya pandangan yang menilai tidak diperlukannya lembaga ini. Selain itu, Putusan DKPP yang bersifat final and binding dinilai menimbulkan efek psikologis bagi jajaran KPU serta Bawaslu berupa ketakutan dan berpotensi menimbulkan polemik hukum yang berkepanjangan. Penelitian ini bertujuan untuk menghasilkan model komunikasi konstitutif DKPP Periode 2012-2017 berdasarkan manajemen pengetahuan. Penelitian ini menggunakan paradigma konstruktivis dan pendekatan kualitatif. Metode yang digunakan yakni studi kasus. Data penelitian ini dikumpulkan melalui wawancara mendalam terhadap tiga Anggota DKPP dan satu koordinator wilayah. Selain wawancara, juga dilakukan studi dokumentasi dan literatur serta observasi. Penelitian ini telah menghasilkan model komunikasi konstitutif DKPP periode 2012-2017 berdasarkan manajemen pengetahuan yang menjelaskan bahwa DKPP sebagai lembaga penegak kode etik berprinsip pada good governance, terutama prinsip keterbukaan dalam membangun kelembagaan, DKPP melakukan sharing meaning dengan mitra utamanya yakni KPU dan Bawaslu RI untuk mengurangi ambiguitas informasi tentang pentingnya kode etik penyelenggara pemilu dan kedudukan lembaga penegak kode etik penyelenggara pemilu sehingga memunculkan kesepakatan mengenai Peraturan Bersama KPU, Bawaslu, dan DKPP Nomor 1, 11, 13 Tahun 2012 tentang Kode Etik Penyelenggara Pemilu, dan Peraturan DKPP Nomor 2 Tahun 2012 tentang Pedoman Beracara Kode Etik Penyelenggara Pemilu. Selanjutnya, DKPP periode 2012-2017 berdasarkan manajemen pengetahuan telah menghilangkan ambiguitas informasi dalam negosiasi keanggotaan, koordinasi aktivitas, pembentukan struktur dan posisi kelembagaan yang merupakan aliran pengorganisasian.
\end{abstract}

Kata-kata Kunci: DKPP; informasi organisasi; komunikasi konstitutif; manajemen pengetahuan; modelisasi

\section{The constitutive communication model of Honorary Board of Election Organizers 2012-2017 period based on knowledge management}

\section{ABSTRACT}

DKPP is an institution whichtake an action needed on violations in the election organizer's code of ethics and is an integral function of the election administration. Nevertheless, in carrying out its duties and authority DKPP faces various challenges, such asrumors that assess the importance for this institution. In addition, the decision of DKPP which is considered as a final and binding decision is assumed to have a psychological effect on the ranks of the KPU and Bawaslu in the form of fearness and potential to cause a prolonged legal polemic. This study aims to produce the DKPP constitutive communication model for the 2012-2017 period based on knowledge management. This study uses a constructivist paradigm and a qualitative approach. The method used is a case study. This research data was collected through in-depth interviews with three DKPP members and one regional coordinator. In addition to interviews, documentation and literature studies and observations were also conducted. This research has produced the constitutive communication model of DKPP 2012-2017 period based on knowledge management which explains that DKPP as an enforcement agency with principles of good governance, especially the principle of openness in building institutions, Openness encourages DKPP to share meaning with Its main partners are KPU and Bawaslu RI to reduce the ambiguity of information about the importance of the code of ethics for election organizer and the position of the electoral code of ethics enforcement agency regulated in Law Number 15 of 2011 concerning Election Organizations. So that it raises an agreement on the Joint Regulation of the KPU, Bawaslu, and DKPP Number 1, 11, 13 of 2012 concerning the Code of Ethics for Election Organizers, and DKPP Regulation Number 2 of 2012 concerning Guidelines on Procedures for the Ethics of Election Organizers, The DKPP for the 2012-2017 period based on knowledge management has eliminated information ambiguity in membership negotiations, activity coordination, formation of institutional structures and positions which constitute an organizational flow.

Keywords: contitutive communication; DKPP; knowledge management; model; organization information

Korespondensi: Irmawanti, S.Ikom., M.Ikom. Dewan Kehormatan Penyelenggara Pemilu. Jalan MH Thamrin No 14, Jakarta Pusat, Daerah Khusus Ibukota Jakarta 10350.Email: irma.tayuka2@gmail.com 


\section{PENDAHULUAN}

Etika merupakan elemen penting yang harus ditaati oleh setiap penyelenggara pemilu, karena merupakan salah satu aspek fundamental dalam mewujudkan pemilu yang demokratis. Sehingga, harapan untuk mewujudkan pemilu yang demokratis dapat tercapai jika penyelenggara pemilu mengedepankan nilainilai etika. Begitu juga sebaliknya, apabila penyelenggara pemilu melanggar nilai-nilai etika, maka akan berpotensi menghambat terwujudnya pemilu yang demokratis (Chakim M. L., 2014).

Untuk mendukung hal tersebut diperlukan pemahaman filosofis mengenai konsep etika bagi penyelenggara pemilu. Etika merupakan bagian tidak terpisahkan dari kehidupan manusia yang beradab, termasuk dalam kehidupan berbangsa dan bernegara (Dharmawan, 2016). Menurut Bertens (dalam Wahid, 2016) etika memiliki tiga makna yakni pertama, nilainilai dan norma-norma moral yang menjadi pegangan bagi seseorang atau suatu kelompok dalam mengatur tingkah lakunya, atau secara singkat dipahami sebagai sistem nilai. Kedua, kumpulan asas atau nilai moral atau kode etik, dan ketiga, ilmu tentang baik dan buruk.

Kesadaran terhadap pentingnya penegakkan etika penyelenggara pemilu di Indonesia ditandai dengan terbitnya UU No. 15 Tahun 2011 tentang Penyelenggaraan Pemilihan Umum. Undang-undang tersebut, melahirkan Dewan Kehormatan Penyelenggara Pemilu, selanjutnya disingkat DKPP. DKPP adalah lembaga yang bertugas menangani pelanggaran kode etik penyelenggara pemilu dan merupakan satu kesatuan fungsi penyelenggaraan Pemilu. DKPP bersifat tetap dan berkedudukan di ibu kota negara dan dibentuk untuk memeriksa dan memutuskan pengaduan dan/atau laporan adanya dugaan pelanggaran kode etik yang dilakukan oleh anggota KPU, anggota KPU Provinsi, anggota KPU Kabupaten/Kota, anggota PPK, anggota PPS, anggota PPLN, anggota KPPS, anggota KPPSLN, anggota Bawaslu, anggota Bawaslu Provinsi dan anggota Panwaslu Kabupaten/Kota, anggota Panwaslu Kecamatan, anggota Pengawas Pemilu Lapangan dan anggota Pengawas Pemilu Luar Negeri. Tujuan didirikannya DKPP sebagai lembaga penegak kode etik diantaranya adalah untuk mewujudkan integritas dari penyelenggara pemilu.

Undang-Undang Nomor 15 Tahun 2011 menjelaskan bahwa penyelenggara pemilu merupakan lembaga yang menyelenggarakan pemilu yang terdiri atas Komisi Pemilihan Umum dan Badan Pengawas Pemilu sebagai satu kesatuan fungsi penyelenggaraan pemilu untuk memilih anggota Dewan Perwakilan Rakyat, Dewan Perwakilan Daerah, Dewan Perwakilan Rakyat Daerah, Presiden dan Wakil Presiden secara langsung oleh rakyat, serta untuk memilih Gubernur, Bupati, dan Walikota secara demokratis.

Komisi Pemilihan Umum selanjutnya disingkat KPU adalah lembaga penyelenggara pemilu yang bersifat nasional, tetap dan mandiri yang bertugas melaksanakan pemilu. KPU harus bersikap independen karena penyelenggara pemilu itu harus bersifat netral dan tidak memihak. KPU itu tidak boleh dikendalikan oleh partai politik ataupun oleh pejabat negara yang mencerminkan kepentingan partai politik atau peserta atau calon peserta pemilihan umum.

Badan Pengawas Pemilu, selanjutnya disingkat Bawaslu adalah lembaga penyelenggara pemilu yang bertugas mengawasi penyelenggaraan Pemilu di seluruh wilayah Negara Kesatuan Republik Indonesia. Pengawasan penyelenggaraan pemilu dilakukan oleh Bawaslu (Badan Pengawas Pemilu), Bawaslu Provinsi, Panitia Pengawas Pemilu (Panwaslu) kabupaten/ kota, Panwaslu kecamatan, Pengawas Pemilu Lapangan (PPL), dan Pengawas Pemilu Luar Negeri (PPLN).

Cikal bakal DKPP adalah Dewan Kehormatan Komisi Pemilihan Umum (DK KPU) yang didirikan pada tahun 2008. DK KPU merupakan lembaga penegak kode etik yang bersifat $\mathrm{Ad} H o c$ dan melekat dengan KPU. Berbeda dengan DK KPU, DKPP bersifat permanen dengan tugas memeriksa dan memutus pengaduan atau laporan adanya dugaan pelanggaran etika penyelenggara pemilu dengan sifat keputusan yang final dan mengikat, sehingga DKPP mempunyai kewenangan lebih kuat karena bisa melakukan pemeriksaan, mengadili, dan memutuskan pengaduan atau laporan dugaan pelanggaran kode etik yang dilakukan penyelenggara pemilu yaitu KPU, Bawaslu, dan jajaran di bawahnya (Adi, 2016). Sehingga, DKPP menjadi harapan baru untuk dapat menjaga kemandirian, kredibilitas dan integritas penyelenggara pemilu melalui 
penegakkan kode etik.

Meskipun demikian, dalam menjalankan tugas dan kewenangannya DKPP menghadapi berbagai tantangan diantaranya pandangan yang menilai tidak diperlukannya lembaga ini. Menurut Munhanif keberadaan DKPP sebagai salah satu penyelenggara pemilu, mengakibatkan sistim pemilu di Indonesia semakin kompleks jika dibandingkan negara demokrasi lainnya. Hal ini disebabkan keberadaan DKPP menambah banyaknya lembaga penyelenggara Pemilu (KPU, Bawaslu, dan DKPP) yang dibentuk untuk mengurusi penyelenggaraan pemilu. Padahal keinginan mewujudkan proses berdemokrasi yang baik, bukan berarti lalu membentuk institusi penyelenggara pemilu sebanyakbanyaknya. Justru, semakin banyak lembaga yang mengurusi proses penyelenggaraan pemilu, maka semakin kompleks masalah yang ditimbulkan, baik dari segi kewenangan, fungsi maupun kelembagaan (Darwis, 2015).

Selain itu, Putusan DKPP yang bersifat final and binding dinilai menimbulkan efek psikologis bagi jajaran KPU serta Bawaslu berupa ketakutan akan sanksi pemecatan atau pemberhentian sementara dan berpotensi menimbulkan polemik hukum yang berkepanjangan (Darwis, 2015). Ketakutan terhadap Putusan DKPP bahkan memunculkan sebutan "malaikat pencabut nyawa" terhadap DKPP di kalangan penyelenggara pemilu. Hal itu dikarenakan banyaknya penyelenggara pemilu yang dijatuhi sanksi pemberhentian tetap. Sejak berdirinya DKPP hingga tahun 2015, di seluruh wilayah Indonesia sejumlah 336 orang penyelenggara pemilu dijatuhi sanksi pemberhentian tetap. Hal tersebut kemudian dinilai menjadikan trauma tersendiri bagi KPU dan Panwas (Hufron, 2015).

Tantangan lain adalah sekretariat DKPP sebagai pendukung pimpinan DKPP dalam menjalankan tugas dan kewenangannya melekat dengan struktur Sekjen Bawaslu. Sebagaimana tertuang dalam UU Nomor 15 Tahun 2011 Pasal 115 yang berbunyi "Dalam melaksanakan tugasnya, DKPP dibantu oleh sekretariat yang melekat pada Sekretariat Jenderal Bawaslu". Hal ini dinilai berpotensi mengganggu kemandirian DKPP dalam menjalankan tugas dan kewenangannya. Menurut Apung Widadi, kelembagaan DKPP perlu berbenah diri dalam hal keorganisasian dan kemandirian dalam bekerja. Dalam arti, pengelolaan anggaran negara, program kerja dan penegakkan etik harus dilakukan secara mandiri agar dapat progresif dan independen. Menurutnya, usulan revisi bentuk DKPP dalam UU Pemilu menjadi mandiri tidak di bawah Bawaslu menjadi relevan dalam hal ini (Widadi, 2013).

DKPP periode 2012-2017 dapat menyelesaikan berbagai tantangan. Meskipun pada awalnya DKPP dinilai kontroversial dan dipenuhi kekhawatiran atas keberadaannya. Di akhir periode 2012-2017, DKPP bahkan mendapat apresiasi dari tokoh-tokoh nasional yang disampaikan dalam forum laporan 5 tahun kinerja DKPP. Ketua MPR Zulkifli Hasan menyebut bahwa keberadaan DKPP telah mengubah penyelenggaraan pemilu jauh lebih baik. DKPP juga telah mampu mengurangi upaya menghalalkan segala cara. Wiranto selaku Menteri Koordinator Bidang Politik, Hukum, dan Keamanan Republik Indonesia juga mengaku bersyukur dengan keberadaan DKPP dalam sistem pemilu di Indonesia. Wiranto juga menilai bahwa yang dapat menyinkronkan kinerja KPU dan Bawaslu adalah DKPP. Apresiasi terhadap kinerja DKPP juga disampaikan oleh Dirjen Otonomi Daerah Kemendagri Soni Sumarsono telah melihat peran DKPP sangat penting. Dia menilai dari kasuskasus yang terjadi selama penyelenggaraan Pemilu dan Pemilukada. Dari penilaian itu, dia yakin DKPP memang harus diperkuat. Salah satunya keberadaan sekretariatnya harus berdiri sendiri dan dipisah dari Bawaslu (Syarwani, 2017).

Apresiasi tersebut menunjukkan DKPP dapat mengkomunikasikan pentingnya lembaga penegakkan kode etik penyelenggara pemilu kepada stakeholders. Komunikasi merupakan unsur yang penting dalam kehidupan organisasi, baik ditinjau dari segi proses administrasi dan manajemen maupun keterlibatan semua pihak di dalam suatu organisasi (Gusfa, 2016 ). Sebuah organisasi memerlukan komunikasi karena digunakan sebagai alat untuk memperlancar jalannya kegiatan dan guna mencapai tujuan yang telah ditetapkan oleh organisasi (Murti, Lestari, \& Ali, 2017).

Pengetahuan menjadi kunci untuk menyelesaikan sebuah permasalahan. Pengetahuan dalam sebuah organisasi perlu dibagi karena pengetahuan dari masing-masing orang berbeda. Pentingnya mengorganisir 
pengetahuan, untuk memahami manajemen pengetahuan (knowledge management) (Prabowo T. T., 2016). Menurut North \& Kumta Knowledge Management (KM) organisasi dapat meningkatkan efisiensi dan efektivitas operasional, berinovasi, dan mengubah kualitas. Knowledge management (KM) merupakan pendekatan sistemik yang membantu memunculkan dan mengalirkan informasi dan pengetahuan kepada orang yang tepat pada saat yang tepat untuk menciptakan nilai. KM memungkinkan individu, tim, dan seluruh anggota organisasi untuk kolektif dan sistematis membuat, berbagi, dan menerapkan knowledge untuk mencapai tujuan. Selain itu, menurut Becerra dan Sabherwal mendefinisikan knowledge management sebagai aktivitasaktivitas dalam menemukan pengetahuan (knowledge discovery), membekukan pengetahuan (knowledge capture), membagikan pengetahuan (knowledge sharing), dan mengaplikasikan pengetahuan (knowledge application) dalam rangka meningkatkan dampak pengetahuan terhadap pencapaian tujuan organisasi dengan memanfaatkan biaya secara efektif (Purwasih \& Sensuse, 2014).

Karl Weick (dalam West \& Turner, 2007) melihat organisasi sebagai sebuah sistem yang mengambil sebuah informasi yang membingungkan atau ambigu dari lingkungannya dan membuat informasi tersebut menjadi masuk akal. Informasi organisasi menggambarkan proses dimana organisasi mengumpulkan, mengelola, dan menggunakan informasi yang mereka terima. Sehingga, yang menjadi fokus utamanya adalah pertukaran informasi yang terjadi dalam organisasi dan bagaimana anggota mengambil langkah untuk memahami hal itu, dengan kejelasan arus informasi memastikan adanya stuktur organisasi yang tegas dalam membangun organisasi. Pentingnya komunikasi dan pengelolaan informasi mengasumsikan penting kehadiran manusia yang creative, aktif dalam mewujudkan ide, inovasi dan mutu. Ada tiga tahapan yang harus dilalui oleh organisasi untuk mengurangi ketidakjelasan informasi, yakni penetapan (enachment), pemilihan (selection), dan penyimpanan (retension). DKPP merupakan lembaga baru dalam dunia kepemiluan, sehingga niscaya terdapat berbagai pandangan yang menilainya. Dengan demikian, untuk dapat berkomunikasi dengan lingkungannya,
DKPP perlu mengolah informasi yang dinilai ambigu. Sehingga terdapat pandangan yang diharapkan sebagaimana amanah UU Nomor 15 Tahun 2011.

Robert McPhee menyebut komunikasi tidak hanya dapat mengurangi ketidakjelasan informasi atau ambiguitas melainkan juga membentuk organisasi (Griffin, 2015). Robert McPhee menyebutnya communications constitute organization. Constitute atau konstitutif dalam communication constitute organizing adalah cara dimana sesuatu yang dibentuk atau dibuat; pengaturannya atau kombinasi dari bagian atau elemennya, sebagai penentu sifatnya dan karakter, buat, bingkai, dan komposisi. "The way in which anything is constituted or made up; the arrangement or combination of its parts or elements, as determining its nature and character; make, frame, and composition" (Putnam \& Nicotera, 2009).

Robert McPhee juga menjelaskan bahwa komunikasi konstitutif organisasi melalui empat aliran yang berbeda. Aliran tersebut yaitu pertama negosiasi keanggotaan (membership negotiation). Negosiasi keanggotaan menghubungkan sebuah organisasi dengan anggotanya dalam membangun dan memelihara hubungan. Kedua, penataan diri (self-structuring). Penataan diri organisasi adalah proses subjektif dan politis yang dapat dipengaruhi oleh sistem, individu, kepentingan, dan tradisi di mana hal itu terjadi. Ini tidak harus bebas dari kesalahan atau ambiguitas. Penataan diri memisahkan organisasi dari kelompok lain seperti kerumunan atau massa. Proses penataan diri dilakukan melalui komunikasi antar pemegang peran dan kelompok. Komunikasi tentang penataan diri bersifat rekursif dan dialogis. Ketiga, posisi institusional (institutional positioning) menghubungkan organisasi dengan lingkungan di luar organisasi pada tingkat makro. Keempat, koordinasi aktivitas (activity coordination), merupakan urutan alur kerja, kebijakan, dan lain-lain yang mengatur untuk koordinasi aktivitas. (McPhee \& Zaug, 2000)

Berdasarkan uraian tersebut, maka penulis berusaha mengidentifikasinya dengan pertanyaan bagaimana model komunikasi konstitutifberdasarkan manajemen pengetahuan menjelaskan langkah DKPP Periode 2012-2017 dalam menghadapi tantangan organisasi. Oleh 
karena itu, penelitian ini bertujuan menghasilkan model komunikasi konstitutif DKPP Periode 2012-2017 berdasarkan manajemen pengetahuan. Hasil penelitian ini diharapkan menjadi acuan DKPP periode 2017-2022 dalam mengembangkan lembaga. Mengingat adanya perubahan undang-undang yang menjadi landasan berdirinya DKPP, yang semula Nomor 15 Tahun 2011 tentang Penyelenggaraan Pemilu diganti Nomor 7 Tahun 2017 tentang pemilu. UU Nomor 7 Tahun 2017 menyebut DKPP sebagai penyelenggara pemilu. Berbeda dengan UU sebelumnya yang menyebut DKPP sebagai satu kesatuan penyelenggara pemilu.

\section{METODE PENELITIAN}

Penelitian ini menggunakan paradigma konstruktivis dan pendekatan kualitatif. Menurut Denzin dan Lincoln, penelitian kualitatif adalah penelitian yang menggunakan latar alamiah, dengan maksud menafsirkan fenomena yang terjadi dan dilakukan dengan jalan melibatkan berbagai metode yang ada (Moleong, 2006). Objek penelitian ini adalah komunikasi konstitutif DKPP berdasarkan manajemen pengetahuan. Penelitian ini dibatasi hanya pada masa bakti DKPP periode 20122017. Metode yang digunakan dalam penelitian ini yakni studi kasus. Studi kasus adalah suatu inkuiri empiris yang menyelidiki fenomena di dalam konteks kehidupan nyata, bilamana batas-batas antara fenomena dan konteks tidak tampak dengan tegas dan dimana berbagai sumber bukti dimanfaatkan. Penelitian studi kasus bertujuan untuk menjelaskan bagaimana keberadaan dan mengapa kasus tersebut terjadi. Penelitian studi kasus bukan sekedar menjawab pertanyaan penelitian tentang 'apa' objek yang diteliti, tetapi lebih menyeluruh dan komprehensif lagi adalah tentang 'bagaimana' dan 'mengapa' (Yin, 2015).

Data pada penelitian ini dikumpulkan melalui wawancara yang mendalam terhadap informan. Wawancara merupakan sumber bukti yang esensial bagi studi kasus, karena studi kasus umumnya berkenaan dengan kemanusiaan. Wawancara yang paling umum dalam studi kasus bertipe open-ended, dimana peneliti dapat bertanya kepada responden kunci tentang fakta-fakta suatu peristiwa di samping opini mereka mengenai peristiwa yang ada (Yin, 2015). Informan penelitian adalah subjek yang memahami objek penelitian sebagai pelaku maupun orang lain yang memahami objek penelitian (Bungin, 2015). Informan dalam penelitian ini adalah Nur Hidayat Sardini, Ida Budhiati dan Endang Wihdatiningtyas yang merupakan Anggota DKPP periode 20122017, serta Purnomo selalu Koordinator Wilayah. Pemilihan informan berdasarkan pada teknik purposive, dimana peneliti mengambil informan berdasarkan kriteria-kriteria tertentu yang penulis buat berdasarkan tujuan riset (Rachmat, 2008). Kriteria informan dalam penelitian ini, pertama informan adalah pelaku dalam kasus yang diteliti. Kedua, informan memiliki kewenangan dalam pengambilan kebijakan terhadap kasus yang diteliti. Selain wawancara, pengumpulan data juga dilakukan dengan teknik studi dokumentasi dan literatur yang dihasilkan oleh DKPP serta observasi.

Teknik analisis data menggunakan model dari Miles dan Huberman. Ada tiga tahap dalam teknik analisa menurut Miles dan Huberman, yakni reduksi data, penyajian data, dan verifikasi (Bungin, 2012). Kemudian untuk memeriksa keabsahan data digunakan teknik triangulasi. Triangulasi adalah teknik pemeriksaan keabsahan data yangmemanfaatkan sesuatuyang lain di luar data itu untuk keperluan pengecekan atau sebagai pembanding terhadap suatu data (Iskandar, 2009). Denzin menyebutkan bahwa cara yang paling penting dan mudah dalam uji keabsahan hasil penelitian adalah dengan melakukan triangulasi. Pelaksanaan teknis dari langkah pengujian keabsahan data yakni dengan memanfaatkan peneliti, sumber, metode, dan teori (Bungin, 2015).

Penelitian ini menggunakan teknik triangulasi sumber untuk memeriksa keabsahan dari data. Menurut Moleong penelitian yang menggunakan teknik triangulasi dalam pemeriksaan melalui sumbernya artinya membandingkan atau mengecek ulang derajat kepercayaan suatu informasi yang diperoleh melalui waktu dan alat yang berbeda (Moleong, 2001). Untuk itu perlu diadakan pengecekan ulang terhadap sumber-sumber data dengan cara (1) membandingkan data hasil pengamatan dengan hasil wawancara, (2) membandingkan apa yang dikatakan oleh seseorang di depan umum dengan yang dikatakan secara pribadi, (3) membandingkan apa yang dikatakan oleh seseorang tentang situasi penelitian dengan apa yang dikatakannya sepanjang waktu, 
(4) membandingkan keadaan dan perspektif seseorang dengan berbagai pendapat dan pandangan orang lain, dan (5) membandingkan hasil wawancara dengan isi dokumen yang berkaitan (Iskandar, 2009).

\section{HASIL DAN PEMBAHASAN}

Pengetahuan adalah informasi yang diinterpretasikan dan diintegrasikan. Laudon (dalam Almah, 2013) menyebut manajemen pengetahuan berfungsi meningkatkan kemampuan organisasi untuk belajar dari lingkungannya dan menggabungkan pengetahuan dalam suatu organisasi untuk menciptakan, mengumpulkan, memelihara dan mendiseminasikan pengetahuan organisasi. Manajemen pengetahuan merupakan kegiatan (Programme, 2011) organisasi dalam mengelola pengetahuan sebagai aset, diperlukan upaya penyaluran pengetahuan yang tepat kepada orang yang tepat dan dalam waktu yang cepat, hingga mereka bisa saling berinteraksi, berbagi pengetahuan dan mengaplikasikannya dalam pekerjaan sehari-hari demi peningkatan kinerja organisasi (Prabowo, 2010).

Herbert A. Simon menjelaskan bahwa tanpa komunikasi tidak mungkin ada organisasi karena kalau begitu maka tidak ada peluang bagi kelompok untuk memengaruhi perilaku seseorang. Tidak saja komunikasi mutlak bagi adanya organisasi, kesediaan beberapa teknik komunikasi tertentu secara garis besar menentukan bagaimana fungsi-fungsi pembuatan keputusan dapat berlangsung dan disebarkan ke seluruh organisasi (Hardjana, 2016).

McPhee dan Zaug sependapat dengan Hardjana yang menyatakan bahwa komunikasi membangun organisasi. Pendapatnya tersebut dituliskan dalam jurnal berjudul "The Communicative Constitution Of Organizations: A Framework For Explanation". Menurut mereka, komunikasi dalam membangun organisasi tidak hanya memerlukan satu, tapi empat jenis pesan, atau lebih khusus lagi jenis aliran pesan atau proses interaksi. Berbagai macam arus pesan diperlukan karena organisasi yang kompleks memerlukan jenis hubungan yang berbeda dengan empat "khalayak". Empat aliran tersebut yaitu membership negotiation untuk mengumumkan dan memelihara hubungan dengan anggota, self-structuring untuk berkomunikasi dengan internal sebagai entitas formal, activity coordination untuk berkomunikasi dengan subkelompok dan proses internal, institutional positioning untuk berkomunikasi dengan koleganya. DKPP sebagai organisasi juga tidak terlepas dari unsur komunikasi dalam pengorganisasiannya.

Pemilu merupakan urusan publik, bekerja untuk publik, dan dalam cara bekerjanya terikat dengan tata kelola pemerintahan yang baik dan bersih. Sebagai bagian dari pelaksanaan kegiatan pemerintahan, pemilu diharuskan memedomani prinsip-prinsip good corporate governance (CGC) meliputi transparansi, akuntabilitas, pertanggungjawaban, kemandirian, dan kewajaran. Sehingga, penyelenggara pemilu didorong untuk mewujudkan good governance, termasuk DKPP yang merupakan satu kesatuan dengan penyelenggara pemilu. Secara konseptual pengertian baik (good) dalam istilah kepemerintahan yang baik (good governance) mengandung dua pemahaman. Pertama adalah nilai yang menjunjung tinggi keinginan/kehendak rakyat, dan nilai-nilai yang dapat meningkatkan kemampuan rakyat dalam pencapaian tujuan (nasional) kemandirian, pembangunan berkelanjutan dan keadilan sosial. Kedua, aspek fungsional dari pemerintah yang efektif dan efisien dalam pelaksanaan tugasnya untuk mencapai tujuan tersebut (Sardini, 2015). UNDP mendefinisikan good governance sebagai hubungan yang sinergis dan konstruktif di antara negara dengan sektor swasta dan masyarakat. Berdasarkan hal ini, UNDP kemudian menetapkan karakteristik good governance (Programme, 2011) yang meliputiparticipation, rule oflaw, transparency, responsiveness, concincus orientation, equity, effectiveness and efficiency, accountability, dan strategic vision.

UU Nomor 15 Tahun 2011 tentang Penyelenggara Pemilu dalam Pasal 111 ayat (1) menyebutkan bahwa "DKPP bersidang untuk melakukan pemeriksaan dugaan adanya pelanggaran kode etik yang dilakukan Penyelenggara Pemilu." Berdasarkan hal itu, DKPP dikonstruksi sebagai semi peradilan atau peradilan khusus etika. Asas persidangan yang dianut DKPP di antaranya adalah asas terbuka untuk umum. Asas sidang terbuka untuk umum adalah suatu asas yang menyatakan bahwa sidang-sidang kode etik penyelenggara pemilu digelar terbuka untuk umum, kecuali dinyatakan 


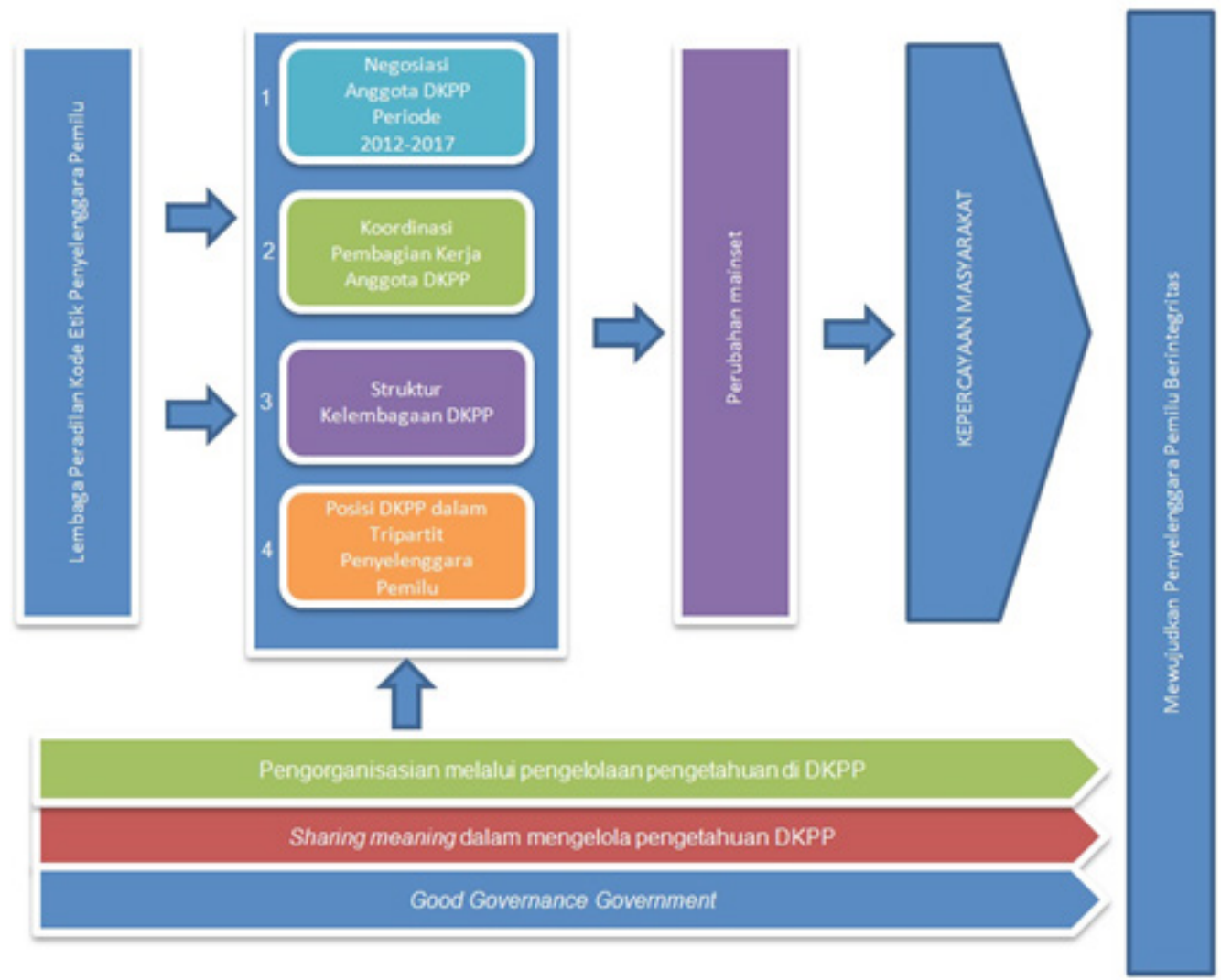

Sumber: Hasil Penelitian, 2018

\section{Gambar 1 Model Komunikasi Konstitutif DKPP Periode 2012-2017 berdasarkan Knowledge Management}

sebaliknya (Sardini, 2015).

Mekanisme beracara sidang terbuka DKPP yakni memberikan kesempatan secara terbuka kepada pihak tertuduh atau disebut dengan Teradu untuk melakukan pembelaan di hadapan majelis sidang, dengan cara memberikan keterangan tertulis serta menghadirkan saksisaksi dan juga bukti. Teradu adalah anggota atau jajaran sekretariat penyelenggara pemilu. DKPP juga memberikan kesempatan yang sama bagi penuduh atau disebut dengan Pengadu. Untuk meyakinkan majelis sidang terhadap dalil aduan yang diajukan ke DKPP, pihak Pengadu dapat menghadirkan saksi-saksi dan bukti dalam sidang pemeriksaan. Pengadu bisa berasal dari rekomendasi DPR, maupun pihakpihak yang berkepentingan seperti pasangan calon, partai pengusung, organisasi masyarakat maupun masyarakat umum.

Weick menjelaskan bahwa untuk mengurangi ketidakjelasan dan ambiguitas organisasi dalam memproses informasi perlu melakukan interpretasi terhadap informasi yang ada di dalam dan di luar lingkungan mereka(West \& Turner, 2007). Kemudian, mengkoordinasikan informasi untuk menjadikannya bermakna bagi anggota dan tujuan organisasi. Collin mendefinisikan informasi adalah pengetahuan yang disajikan kepada seseorang dalam bentuk yang dapat dipahami, atau data yang telah diproses atau ditata untuk menyajikan fakta yang mengandung arti. Informasi yang diinterpretasikan dan diintegrasikan disebut sebagai pengetahuan (Siregar, 2005)

Selanjutnya, aktivitas-aktivitas dalam menemukan pengetahuan (knowledge discovery), membekukan pengetahuan (knowledge capture), membagikan pengetahuan (knowledge sharing), dan mengaplikasikan pengetahuan (knowledge application) dalam rangka meningkatkan dampak pengetahuan terhadap pencapaian tujuan organisasi dengan memanfaatkan biaya secara efektif disebut Becerra dan Sabherwal sebagai manajemen pengetahuan (Sensuse \& Purwasih, 2014). Menurut Weick, ada tiga tahapan proses informasi yaitu enactment, seleksi dan retensi untuk mengurangi ketidakjelasan informasi dan ambiguitas. Nonaka (dalam Anttiroiko, 2009) menambahkan "change" dalam tahapan proses informasi Weick untuk menjelaskan bagaimana proses pengetahuan dioperasionalkan. Nonaka mendefinisikan proses pengetahuan sebagai proses organisasi di mana informasi 


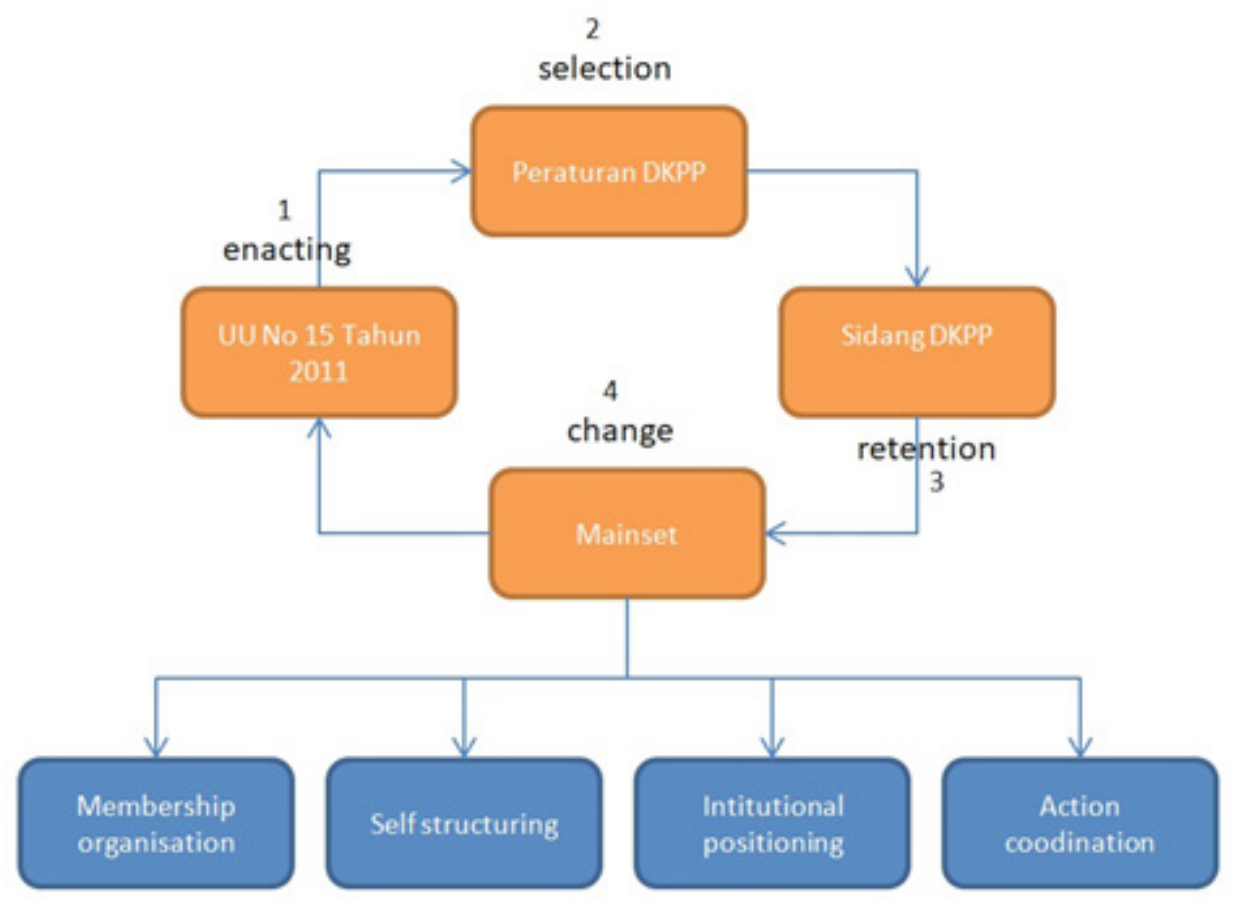

Sumber: Hasil Penelitian, 2018

\section{Gambar 2 Sharing Meaning dalam Mengelola Pengetahuan DKPP}

dikumpulkan, dibuat, diproses, digunakan, dan dibubarkan untuk membentuk basis orientasi yang diperkaya untuk menjaga fungsi dasar organisasi.

Proses informasi DKPP pada tahap enacting dengan menginterpretasi UndangUndang Nomor 15 Tahun 2011. Undang-undang tentang penyelenggaraan pemilu ini merupakan landasan didirikannya DKPP. Komisi II DPR RI bersama dengan pemerintah sebagai pembuat undang-undang tersebut memaktubkan tujuan, tugas dan kewenangan DKPP di dalamnya. Pada tahapan ini, DKPP memproses informasi tentang lembaga penegak kode etik.

Ketua DKPP Prof. Jimly Asshiddiqie melihat masalah etika harus terus berkembang seperti halnya kajian fiqih dalam Islam. Oleh sebab itu, lembaga-lembaga Negara harus dilengkapi dengan kode etik dan lembaga penegaknya. Jadi setiap sumpah jabatan hendaknya mendapat kontrol etika sehingga orang-orang yang melanggar kode etik, bisa diberikan hukuman sesuai perbuatannya. Tidak seperti lembaga penegak kode etik yang ada saat ini yang sebagian besar masih bersifat proforma. Bahkan sebagian di antaranya belum pernah menjalankan tugasnya dengan efektif dalam rangka menegakkan kode etik (DKPP, 2014).

Menurut Prof. Jimly Asshiddiqie diantara sebabnya adalah lembaga-lembaga penegak kode etik yang ada tidak memiliki kedudukan yang independen, sehingga kinerjanya tidak efektif. Karena itu, sebagai solusinya, lembagalembaga penegak kode etik tersebut harus direkonstruksikan sebagai lembaga peradilan etik yang diharuskan menerapkan prinsipprinsip peradilan yang lazim di dunia modern, terutama soal transparansi, independensi, dan imparsialitas. Hal itulah yang hendak dirintis dan dipelopori Dewan Kehormatan Penyelenggara Pemilu (DKPP), yaitu agar sistem ketatanegaraan didukung oleh sistem hukum dan sistem etik yang bersifat fungsional. Sistem demokrasi yang dibangun diharapkan dapat ditopang oleh tegak dan dihormatinya hukum dan etika secara bersamaan.

Adabanyakinterpretasiyang bisa digunakan dalam suatu kejadian. Untuk mengurangi equivocality, Weick merumuskan assembly rules dan communication cycle. Assembly rules (peraturan buatan) adalah prosedur yang bisa memandu anggota organisasi dalam menetapkan pola tertentu dari proses sense making. Akan tetapi, ketika equivocality sedang tinggi, anggota organisasi melakukan communication cycle (siklus komunikasi). Melalui communication cycle, anggota organisasi berusaha memahami situasi dalam lingkungan yang equivocality. Penggunaan assembly rules dan communicaton 
cycle sangat penting dalam selection stage dalam teori Weick.

DKPP dalam mewujudkan kualitas penanganan pelanggaran kode etik penyelenggaraan pemilihan umum menyusun peraturan bersama yang dituangkan dalam Peraturan Bersama KPU, Bawaslu, dan DKPP Nomor 1, 11, 13 Tahun 2012 tentang Kode Etik Penyelenggara Pemilu, dan Peraturan DKPP Nomor 2 Tahun 2012 tentang Pedoman Beracara Kode Etik Penyelenggara Pemilu sebagai teknis operasional terhadap UU yang ada. Adapun tujuan penyusunan peraturan bersama ini untuk menjaga inde pendensi lembaga penyelenggara pemilu. Memberikan pendidikan politik pada warga negara agar berpartisipasi secara efektif, menciptakan kesetaraan keadilan, memberikan pemahaman yang jelas, menjadi bagian dari pengendalian agenda tugas dan menciptakan suatu kesadaran agar semua pemangku kepentingan turut mewujudkan kualitas penanganan pelanggaran kode etik pemilu. "Penyusunan pedoman beracara dan kode etik menjadi pembahasan dalam pleno pertama (Sardini, 2017).

Weick menyebut tahapan ketiga dalam proses informasi untuk mengurangi ketidakjelasan atau ambiguitas adalah retensi. Retensi merupakan informasi yang disimpan atau diingat oleh organisasi dan setiap individu yang menjadi anggotanya. Informasi yang disimpan nantinya akan di gabungkan dengan informasi lainnya yang sudah ada yang akan di gunakan organisasi dalam melaksanakan kegiatannya di masa depan. Dengan demikian peraturan DKPP yang sudah terbentuk digunakan untuk keperluan penanganan dugaan pelanggaran kode etik penyelenggara pemilu yang dilaporkan ke DKPP.

Peraturan bersama yang dituangkan dalam Peraturan Bersama KPU, Bawaslu, dan DKPP Nomor 1, 11, 13 Tahun 2012 tentang Kode Etik Penyelenggara Pemilu, dan Peraturan DKPP Nomor 2 Tahun 2012 tentang Pedoman Beracara Kode Etik Penyelenggara Pemilu sebagai teknis operasional terhadap UU yang ada akan digabungkan dengan informasi yang didapatkan dalam sidang DKPP. Persidangan Kode Etik Penyelenggara Pemilu adalah mekanisme yang digunakan untuk melakukan pemeriksaan dan menetapkan Putusan atas pengaduan/laporan dugaan pelanggaran kode etik penyelenggara Pemilu. Pengaduan/Laporan yang diperiksa melalui persidangan adalah Pengaduan/Laporan yang telah dinyatakan memenuhi syarat baik formil maupun materiil.

Robert D. McPhee dan Pamela Zaug menjelaskan terbentuknya organisasi dengan Communication Constitutes Organization (CCO). Terdapat empat jenis aliran komunikatif yang menghasilkan struktur sosial melalui interaksi. Meskipun berbeda, namun dapat saling mempengaruhi satu sama lain dalam model dan mengarah pada percakapan multiway. McPhee dan Zaug mengidentifikasi aliran ini sebagai membership negotiation, self-structuring, activity coordination, and institutional positioning. Organisasi publik memiliki dan memproses informasi dalam jumlah yang besar baik dari internal maupun eksternal. Inilah sebabnya mengapa dalam melakukan pengorganisasian yang paling penting adalah mengelola proses pengetahuan dan mendukung praktik berbagi pengetahuan. Menurut Nonaka \& Takeuchi, Knowledge Management (KM) adalah alat manajemen yang membenarkan keyakinan bahwa pengetahuan menjadi aset untuk meningkatkan kapasitas organisasi agar mampu bekerja lebih efektif.

Dewan Kehormatan Penyelenggara Pemilu (DKPP) merupakan lembaga yang baru didirikan pada 12 Juni 2012. DKPP sebagai lembaga peradilan kode etik, penting untuk melakukan sharing meaning dan pengorganisasian lembaga melalui pengelolaan pengetahuan terutama kepada mitra utamanya yakni KPU dan Bawaslu. Hal itu tidak terlepas dari tujuan dibentuknya DKPP yakni mewujudkan penyelenggara pemilu yang berintegritas. Robert McPhee menyebutkan bahwa negosiasi keanggotaan menghubungkan sebuah organisasi dengan anggotanya dalam membangun dan memelihara hubungan.

DKPP Periode 2012-2017 memiliki tujuh orang anggota terdiri terbagi dalam tiga unsur yakni DPR, pemerintah dan penyelenggara pemilu. Pertama, unsur perwakilan DPR yakni Jimly Asshiddiqie yang merangkap sebagai Ketua. Selain Jimly, Nur Hidayat Sardini dan Saut Hamonangan Sirait juga perwakilan dari unsur DPR. Kedua, unsur pemerintah yakni Bari Azed dan Valina Singka Subekti. Ketiga, unsur penyelenggara pemilu yakni Ida Budhiati perwakilan dari KPU RI dan Nelson Simanjuntak perwakilan dari Bawaslu RI. Anggota DKPP periode 2012-2017 dilantik 


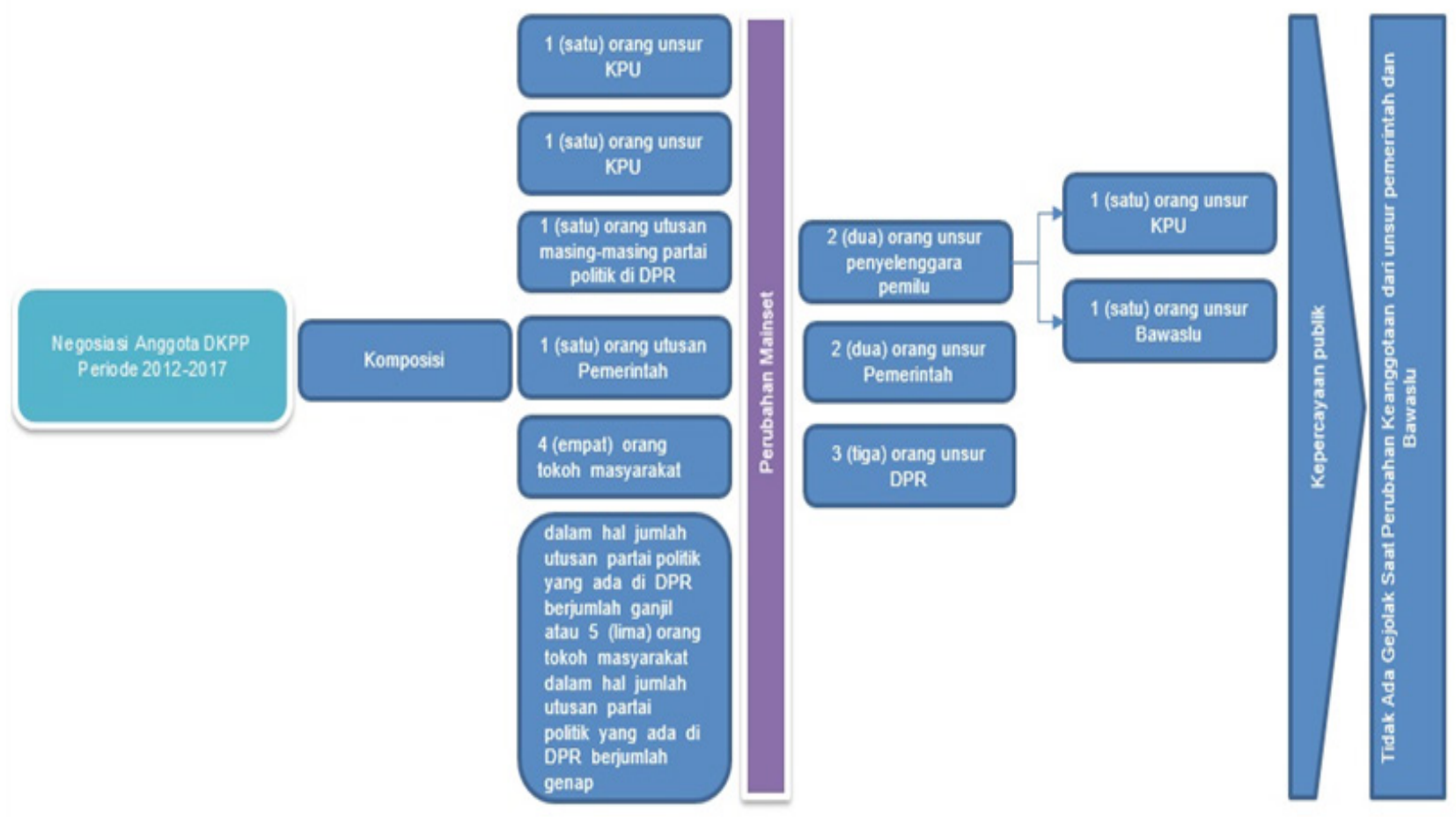

Sumber: Hasil Penelitian, 2018

\section{Gambar 3 Model Negosiasi Keanggotaan DKPP Periode 2012-2017 Berdasarkan Knowledge Management}

oleh Presiden RI Susilo Bambang Yudhoyono bertempat di istana Presiden di Jakarta pada tanggal 12 Juni 2012.

Memenuhi UU Nomor 15 Tahun 2011 Pasal 110 dan seterusnya dan keputusan MK yang mengubah terhadap komposisi, lalu oleh putusan MK sehingga ada tiga anggota DKPP pilihan DPR RI itu adalah Prof Jimly, saya dan pak Saut, kalau pemerintah mengajukan dua nama bu Valina dan Prof Bari. Ex officio ibu Ida dan pak Nelson.

Komposisi keanggotaan DKPP semula berdasarkan "Pasal 109 ayat (4) terdiri dari 1 (satu) orang unsur KPU, 1 (satu) orang unsur Bawaslu, 1 (satu) orang utusan masing-masing partai politik yang ada di DPR, 1 (satu) orang utusan Pemerintah, 4 (empat) orang tokoh masyarakat dalam hal jumlah utusan partai politik yang ada di DPR berjumlah ganjil atau 5 (lima) orang tokoh masyarakat dalam hal jumlah utusan partai politik yang ada di DPR berjumlah genap. Kemudian melalui PUTUSAN MK Nomor 81/PUU-IX/2011 maka ditetapkan keanggotaan DKPP terdiri dari tiga unsur yakni dua orang dari penyelenggara pemilu, tiga orang perwakilan DPR dan dua orang perwakilan pemerintah.

Selama periode 2012-2017, terdapat dua kali pergantian anggota DKPP. Pertama, dari unsur pemerintah yakni Bari Azed yang digantikan oleh Anna Erliyana. Kedua, pergantian dari unsur penyelenggara pemilu yakni Nelson Simanjuntak yang digantikan oleh Endang Wihdatiningtyas. Alasan pergantian dari unsur Bawaslu RI, Endang Wihdatiningtyas menjelaskan bahwa:

Di Bawaslu memang ada pergantian, personil keanggotaan DKPP waktu itu ya. Karena memang di Bawaslu waktu itu ada wacana pergantian dan ini pertama memberi kesempatan kepada anggota yang lain juga untuk bisa merasakan, menambah ilmu jika menjadi ex officio di DKPP.

Koordinasi menjadi bagian penting dalam membangun organisasi. Robert McPhee menyebut bahwa koordinasi dapat membangun lembaga. Anggota DKPP di awal pembentukan adalah dengan melakukan koordinasi pembagian kerja. Pembagian kerja dilakukan dalam penyusunan peraturan DKPP yakni pedoman beracara dan kode etik penyelenggara pemilu.

Saya mengajukan pleno untuk pembagian tugas dalam bentuk Pokja. Pokja terbagi menjadi dua, pertama yang membahas kode etik itu pak Saut, ibu Valina dan pak Nelson. Kedua, Pokja yang membahas pedoman beracara yaitu saya bersama 


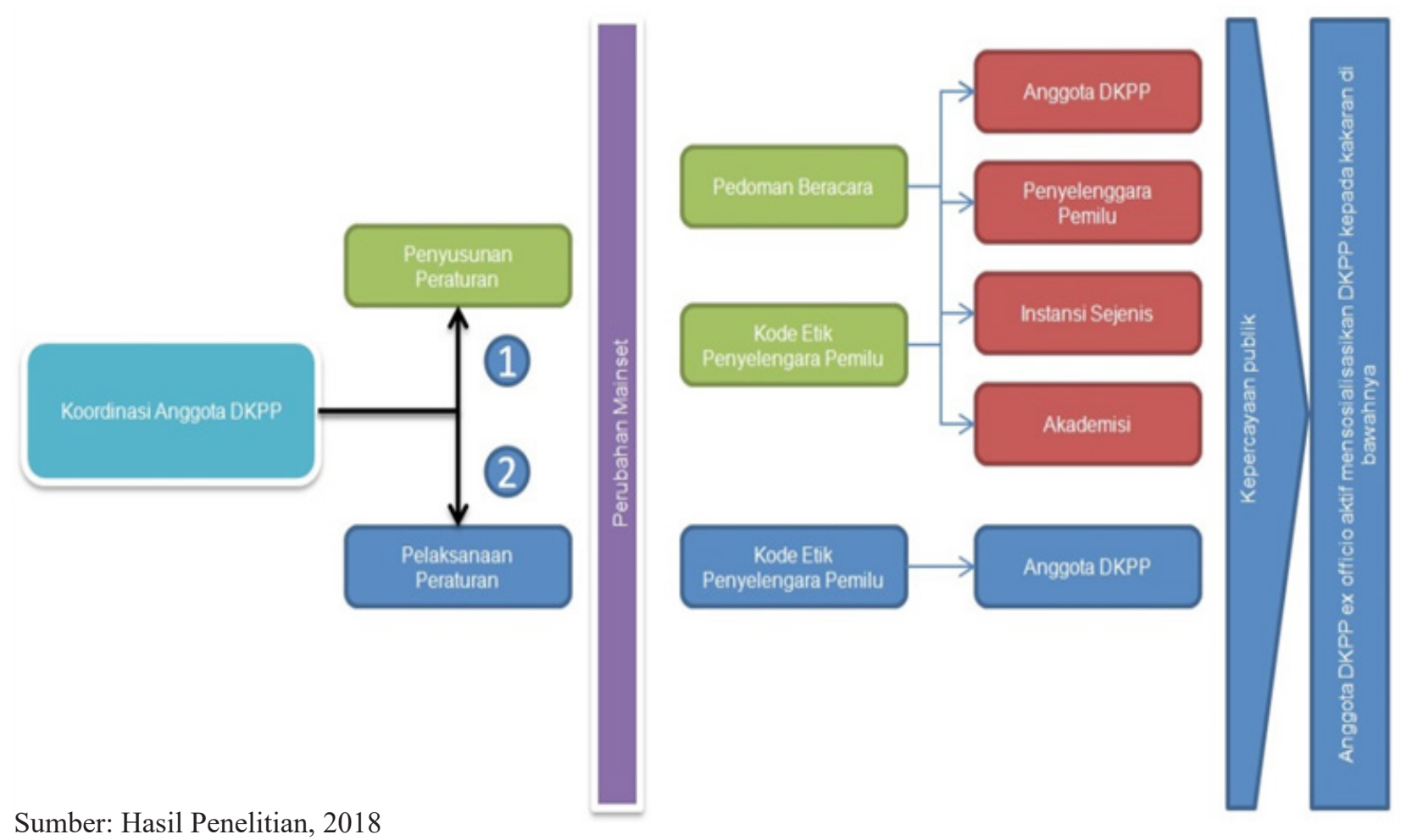

Sumber: Hasil Penelitian, 2018

\section{Gambar 4 Model Koordinasi Pembagian Kerja Anggota DKPP Periode 2012-2017 Berdasarkan Knowledge Management}

dengan ibu Ida dan Prof. Bari.

\section{Dewan Kehormatan Penyelenggara} Pemilu (DKPP) periode 2012-2017 merupakan lembaga baru. Sehingga coordination action anggota DKPP yakni membangun kelembagaan sebagaimana tugas dan fungsinya yang dimaktubkan dalam UU Nomor 15 Tahun 2011. DKPP bertugas menerima, memeriksa dan memutus perkara dugaan pelanggaran kode etik. DKPP dalam membangun kelembagaan juga melakukan coordination action untuk membentuk sekretariat DKPP. Anggota DKPP Nur Hidayat Sardini, melalui forum pleno diberikan amanah untuk mempersiapkan sekretariat DKPP.

Praktis di sekretariatan saya yang pegang, dalam posisi jabatan penanggungjawab sementara sekretariat DKPP. Dari hal yang bersifat teknis, surat-menyurat, administrasi. Apalagi saat itu Prof Jimly melimpahkan praktis ke saya semua. Lalu secara praktis kita juga menerima pengaduan dan melakukan verifikasi. Jadi yang saya kerjakan itu surat-menyurat, perencanaan sosialisasi, merencanakan terhadap kode etik, pedoman beracara sambil jalan lalu membentuk dan merekrut kesekretariatan. Termasuk keharusan membentuk struktur DKPP bagian dari struktur kesekretariatan jenderal Bawaslu.

Ida Budhiati yang merupakan anggota DKPP ex offfcio dari KPU selain menyusun kode etik penyelenggara pemilu juga melakukan sosialisasi di internal KPU dan jajarannya. Ida mensosialisasikan tugas dan kewenangan dari DKPP yang bersentuhan langsung dengan penyelenggara pemilu dalam hal penegakkan kode etik.

Pasti dalam setiap pertemuan diberikan pencerahan. Mengapa dibentuk DKPP permanen, maksud dan tujuan, dan bagaimana penyelenggara pemilu dapat beradaptasi terhadap DKPP yang permanen. Penyelenggara pemilu tidak perlu menakuti justru menjadi spirit untuk selalu berbenah memperbaiki aspek administrasi pemilu. Kebanyakan pemilu dinyatakan tidak profesional, karena aspek administrasi pemilu. Tugas ex officio itu menjelaskan di dalam forum-forum internal "ini tho selama satu tahun tren pelanggaran kode etik seperti ini, maka yang harus dilakukan penyelenggara adalah satu, dua tiga dan seterusnya.

Selain Ida, tindakan serupa juga dilakukan 
oleh Endang Wihdatiningtyas selaku anggota DKPP ex officio dari Bawaslu RI. Dia yang ditugaskan untuk mengurusi SDM di Bawaslu, memanfaatkannya untuk melakukan pembinaan terhadap tugas dan kewenangan dari DKPP.

Karena saya yang di DKPP, saya bisa memberikan gambaran "oh pelanggaran yang dilaporkan ke DKPP itu dengan model seperti ini. Kan kita bisa mempelajarinya agar peristiwa yang dilaporkan itu tidak terjadi di lembaga pengawas, apa-apa yang dilakukan. Nah itu senantiasa saya lakukan ketika ada kesempatan memberikan arahan. Itu secara kelembagaan.

Koordinasi keanggotaan DKPP periode 2012-2017 lainnya yakni penanggung jawab verifikasi materiel perkara yang dinyatakan telah memenuhi syarat administrasi dan penyusunan putusan. Anggota DKPP melakukan kegiatan verifikasi materiel terhadap pokok aduan yang dinilai memenuhi syarat formal pengaduan yang ditetapkan oleh DKPP. Syarat formal yang dimaksud adalah pihak Pengadu melengkapi formulir pengaduan dan menyertakan dua alat bukti.

Untuk verfikasi materiel itu pak NHS, Ibu Ida Budhiati sama pak Nelson Simanjuntak waktu itu. Untuk penanggungjawab sidang itu ada pak Saut terus ibu Valina tapi itu tetap sering berubah-berubah. Ada rolling yang berlangsung setiap tiga bulan sekali berdasarkan hasil pleno.

Robert McPhee dan Pamela Zaug menjelaskan bahwa self structuring adalah proses komunikasi antara pemegang peran dan kelompok organisasi. Self structuring tidak secara langsung memperhatikan pekerjaan, melainkan hubungan internal, norma, dan entitas sosial yang merupakan kerangka untuk koneksi, perampingan, dan pembentukan proses kerja.UU Nomor 15 Tahun 2011 Pasal 115 menjelaskan bahwa dalam melaksanakan tugasnya, DKPP dibantu oleh sekretariat yang melekat pada Sekretariat Jenderal Bawaslu. Meskipun demikian, setelah anggota DKPP dilantik, sekretariat DKPP definitif belum terbentuk hingga tahun 2013. Terdapat kekosongan sekretariat DKPP definitif dikarenakan Sekretariat Jenderal Bawaslu baru terbentuk pada tahun 2013 dengan di lantiknya Gunawan Suswantoro yang sebelumnya menjabat sebagai Kepala Sekretariat Bawaslu menjadi Sekretariat Jenderal Bawaslu.

Selama belum terbentuk sekretariat DKPP definitif, anggota DKPP melalui pleno sepakat menunjuk Nur Hidayat Sardini sebagai penanggung jawab sementara sekretariat DKPP. Penunjukan Nur Hidayat Sardini disepakati pada pleno kedua Jumat 15 Juni 2012. Nur Hidayat Sardini bertanggung jawab kepada Ketua DKPP

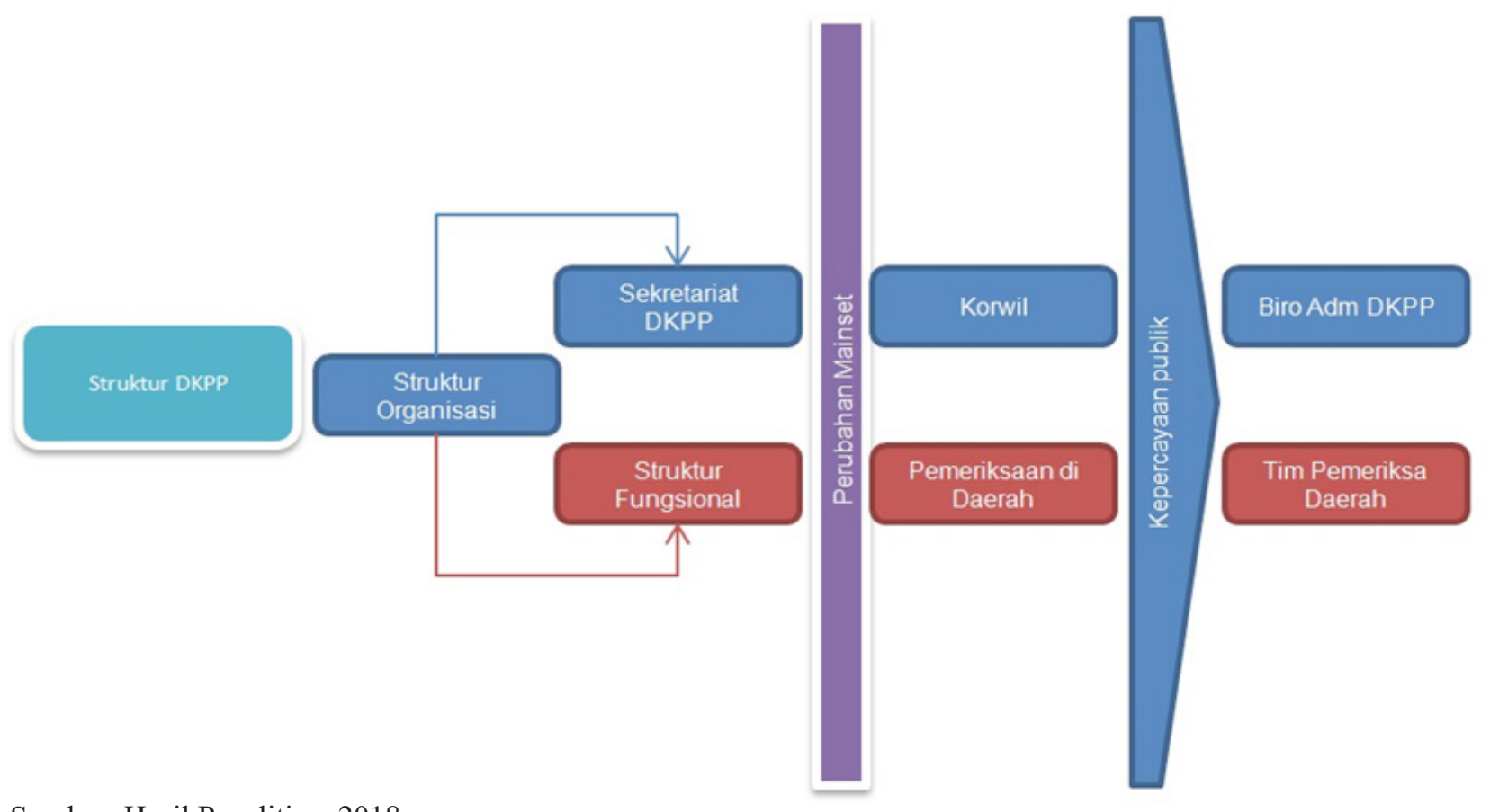


dengan tugas-tugas mengoperasionalisasikan sehari-hari sekretariat DKPP hingga terbentuk definitifnya satu biro di dalam struktur Sekretariat Jenderal Bawaslu. Di samping itu juga bertugas untuk membentuk sekretariat dengan koordinasi para pihak terkait sehingga memungkinkan bagi DKPP menjalankan tugas dan wewenangnya.

Perjalanan mewujudkan sekretariat DKPP definitif menurut Nur Hidayat Sardini tidaklah mudah. Awal terbentuknya DKPP, lembaga baru ini dipandang kecil sehingga sekretariat DKPP diajukan ke KemenpanRB hanya setingkat Bagian. Sedangkan, menurut Nur Hidayat Sardini DKPP meskipun lembaga baru tetapi memiliki kewenangan yang besar. Sehingga perlu didukung setidaknya sekretariat setingkat biro dalam struktur sekretariat Bawaslu RI. "Kita juga berjuang di KemenpanRB dua tiga kali. Disela-sela pembahasan kode etik saya ke KemenpanRB." (Sardini, 2017)

Terhadap problematika struktur sekretariat DKPP tersebut, Nur Hidayat Sardini mempertemukan ketua DKPP Prof. Jimly Asshiddiqie dengan Abu Bakar Azar selaku Menteri PANRB. Pertemuan berlangsung informal, ketika buka bersama di KemenPANRB. Hasilnya, KemenPANRB menyetujui sekretariat DKPP setingkat dengan biro.

Waktu itu sudah mepet. Saya menyarankan Prof Jimly ketemu menteri saja. Itu bulan puasa, akhirnya Prof Jimly saya kondisikan untuk bisa ketemu dengan menteri Abu Bakar Azar. Lalu akhirnya bisa buka bersama di kementerian itu, kemudian saya diajak tapi saya sedang memipin rapat. Setelah itu, baru saya perkuat lagi susunan strukturalnya. Mulanya aduh memilukan sekali kalau tidak paham struktur macam SOTK, apa jadinya kalau cuma satu bagian. Kita sekarang satu biro saja kedodoran.

Dalam peraturan Bawaslu yang mengatur tentang struktur organisasi dan tata kerja Sekretariat Jenderal Bawaslu, DKPP dikerangkakan dalam satu biro Kode Etik Penyelenggara Pemilu yang disebut dengan Sekretariat biro administrasi DKPP. Resmi terbentuk pada tanggal 19 Juli 2013 ditandai dengan dilantiknya kepala biro administrasi DKPP Ahmad Khumaidi, SH., MH. oleh Sekretaris Jenderal Bawaslu RI Gunawan
Suswantoro yang bertempat di media center Bawaslu RI, Jl MH Thamrin 14 Jakpus. Kepala biro administrasi DKPP membawahi tiga bagian, yakni bagian administrasi persidangan, bagian administrasi pengaduan dan bagian administrasi umum. Selama mempersiapkan sekretariat DKPP, Koordinator untuk wilayah Sulawesi Purnomo menjelaskan bahwa untuk mendukung kinerja dari Anggota DKPP disepakati disusun struktur pengganti sementara yang disebut dengan KORWIL.

Korwil wilayah untuk sidang-sidang di DKPP maupun penerimaan pengaduan di DKPP karena saat itu jumlah personil DKPP hanya masih 8 , atau 6 orang atau sekitar 15 orang begitu. Terus disitu belum adanya struktural Kabag, Kasubbag. Jadi Korwil itu menggantikan adanya Kabag, Kasubbag sama untuk struktruran ke pimpinan. Sejarah dibentuknya Korwil yaitu karena untuk mempermudah atau mempercepat sidang-sidang atau penanganan aduan ke DKPP.

Selain menyusun struktur formal dibawah kepemimpinan Sekretaris Jenderal Bawaslu RI dan Korwil. DKPP juga menyusun Tim Pemeriksa Daerah atau yang biasa disebut TPD berdasarkan pada Undang-Undang Nomor 15 Tahun 2011. Kemudian dimaktubkan dalam peraturan DKPP nomor 2 Tahun 2013 tentang pemeriksaan pelanggaran kode etik penyelenggara pemilu di daerah pasal 2 ayat 1 yang bunyinya "Untuk memeriksa dugaan pelanggaran kode etik penyelenggara pemilu di daerah, DKPP dapat membentuk Tim Pemeriksa. Terdiri dari satu anggota DKPP, dua tokoh masyarakat (akademisi), serta penyelenggara pemilu ditingkat provinsi masing-masing satu orang. TPD bersifat Ad Hoc dengan Surat Keputusan yang berlaku satu tahun dan ditanda tangani oleh ketua DKPP. Tugasnya adalah melakukan pemeriksaan perkara dugaan pelanggaran kode etik penyelenggara pemilu di daerah. Tim Pemeriksa Daerah dalam menjalankan tugasnya dibantu oleh dua orang staf Bawaslu provinsi di masing-masing daerah. Staf tersebut diberi Surat Keputusan oleh Sekretaris Jenderal Bawaslu RI.

TPD ini adalah produk DKPP, sekarang diundangkan. Kemudian ada peraturan tentang hubungan antara KPU, Bawaslu dan DKPP terkait dengan tata kerja di 


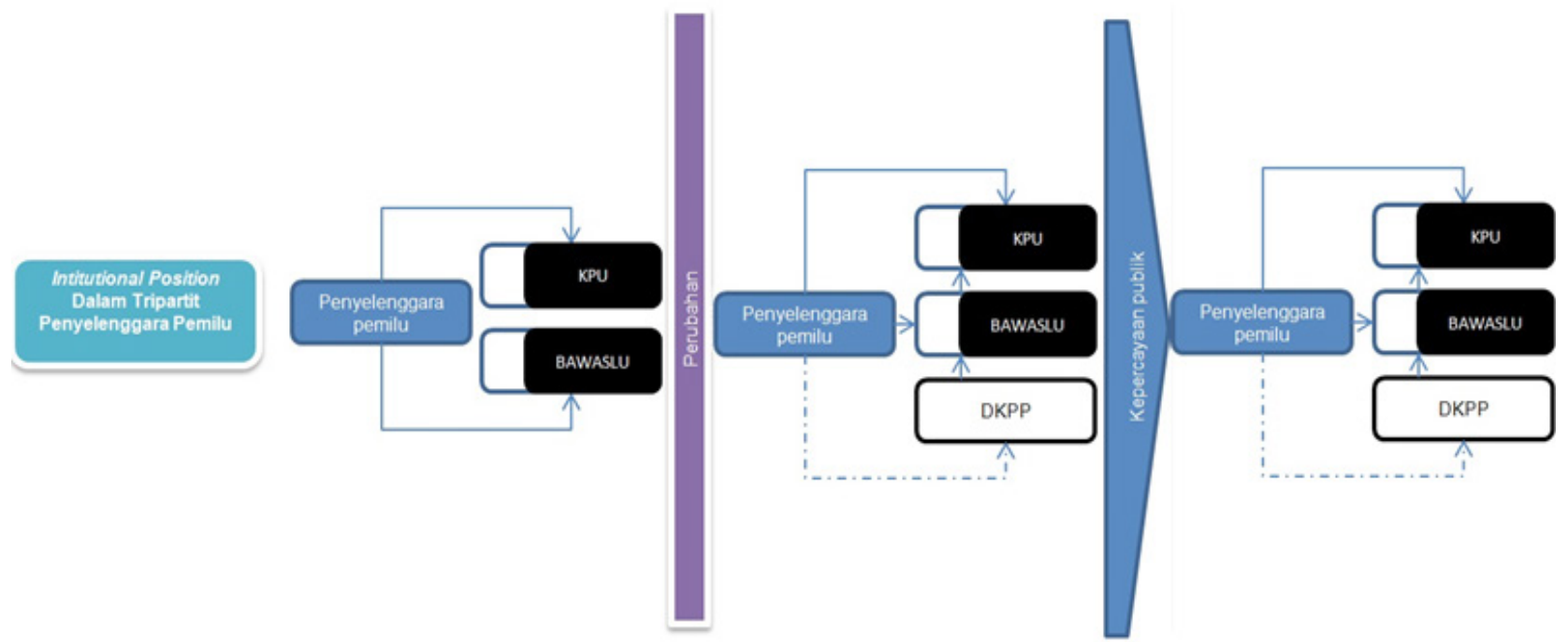

Sumber: Hasil Penelitian, 2018

\section{Gambar 6 Model Intitutional Position DKPP Periode 2012-2017 Dalam Tripartit Penyelenggara Pemilu Berdasarkan Knowledge Management}

pedoman beracara. Jelas sekali ada dasar hukumnya dan bukan semata-mata karna asal tanpa dasar.

Robert McPhee menjelaskan institutional position menghubungkan organisasi dengan lingkungan di luar organisasi pada tingkat makro. "Negosiasi identitas" atau "positioning" merupakan komunikasi di luar organisasi yang menegosiasikan persyaratan pengakuan dari organisasi. DKPP dalam menunjukkan posisinya diantara lembaga penyelenggara pemilu sudah sudah eksis terlebih dahulu diawalinya dengan melibatkan penyelenggara pemilu yakni KPU dan Bawaslu dalam penyusunan peraturan DKPP tentang kode etik penyelenggara pemilu dan pedoman beracara. DKPP mendapat amanah untuk menyusunnya bersama dengan stakeholder. Sebagaimana ketentuan dalam Pasal 101 ayat (2) dalam Undang-Undang Nomor 15 Tahun 2011 tentang Penyelenggara Pemilu, "dalam hal penyusunan kode etik, DKPP dapat mengikutsertakan pihak lain." Sehingga DKPP mengadakan pertemuanpertemuan dengan berbagai stakeholders terutama dengan KPU dan Bawaslu yang menjadi mitra utama.

Kemudian disebut dengan Tripartit (KPU, Bawaslu dan DKPP). Pelibatan penyelenggara pemilu merupakan hasil pemaknaan artikulatif yang dilakukan DKPP, sebagaimana cuplikan dalam wawancara dengan Nur Hidayat Sardini.

Kami juga mengundang para pemangku kepentingan. Kemudian pemangku kepentingan itu tadi kita maknai lebih artikulatif dengan mengundang pertama ketua anggota KPU lama, ketua anggota Bawaslu lama lalu.

Fungsi dari Tripartit mengalami perkembangan yang semula hanya untuk mendapatkan masukan terhadap peraturan DKPP. Kemudian berkembang menjadi kebutuhan lembaga untuk berbagi informasi publik terhadap sesama lembaga penyelenggara pemilu Sebagaimana yang disampaikan Ida Budhiati selaku anggota DKPP ex officio KPU.

Tripartit sebetulnya diwadahi oleh norma hukum disebut bahwa KPU, Bawaslu dan DKPP masing-masing mempunyai kemandirian untuk melakukan tugas dalam satu kesatuan fungsi itu ada di dalam UU Nomor 15 Tahun 2015 dan memahami ini satu kesatuan fungsi kelembagan penyelenggara maka sekalipun DKPP dikonstruksi sebagai lembaga peradilan tidak menutup ruang untuk berkomunikasi, berkoordinasi untuk maksud dan tujuannya adalah memperbaiki aspek tata kelola pemilu. Tata kelola pemilu kan masingmasing lembaga punya kewajiban untuk memberikan akses data informasi. Nah, bagaimana masing-masing institusi ini dapat saling bertukar informasi. KPU, Bawaslu dan DKPP bisa bertukar data dan informasi yang kaitannya dengan pelayanan informasi publik. Maupun pelaksanan tugas dan wewenang masing-masing. 
Mendudukkan KPU dan Bawaslu dalam satu forum bahkan berbagi gagasan, dalam sejarah kepemiluan baru dapat dilakukan DKPP sebagai pencetus Tripartit. Endang mengakui bahwa Tripartit memiliki manfaat dalam mendukung pelaksanaan pemilu yang berintegritas.

Kalau Tripartit itu seingat saya idenya DKPP. Tidak ada perintah undangundang untuk penamaan Tripartit itu. Tetapi ini memang terasa dampaknya karena ketika ada semacam kebuntuan dalam memutuskan suatu permasalahan itu bisa melibatkan DKPP. Walaupun pengambilan keputusan dipleno masingmasing baik KPU dan Bawaslu. Dan menurut saya adalah kelebiasaan baik yang harus dilanjutkan untuk menemukan atau menghasilkan keputusan-keputusan yang sangat bermanfaat untuk tiga lembaga. Mengapa demikian, karena ketika ada suatu masalah dan didiskusikan oleh tiga lembaga ini KPU dan Bawaslu memiliki penguatan atau support dalam hal pengambilan keputusan dan ini juga salah satu bentuk untuk mengurangi, bahasanya kegaduhan ya. Kegaduhan yang bisa terjadi diantara dua penyelenggara. Ini juga sebagai jembatan lembaga dan di periode 2012-2017 ada beberapa potensi masalah yang bisa diselesaikan lewat lembaga Tripartit.

Manfaat Tripartit tidak hanya dirasakan oleh KPU dan Bawaslu, begitupun DKPP yang awal berdiri belum memiliki dukungan sekretariat. Nur Hidayat Sardini menjelaskan bahwa dalam hubungan Tripartit, DKPP juga memfungsikannya sebagai fungsi fasilitasi dalam menjalankan tugas dan kewenangan.

DKPP hanya instansi karbitan murni yang tidak punya aparat, provinsi dan seterusnya, dan karena itulah kami memerlukan. Ada langkah-langkah yang bersifat koordinatif. Sidang baru dimulai akhir 2012 atau akhir tahun 2013. Kami sidang-sidang mengharuskan meminjam di KPU, lalu di Bawaslu karena kan jauh lebih intensif. Jauh lebih bermakna kalau koordinasi dibarengi dengan koordinasi bersifat fasilitasi, karena DKPP sendiri tidak punya aparatnya sarana dan prasana.
Fasilitasi yang dilakukan oleh KPU dan Bawaslu merupakan hasil kesepakatan KPU dan Bawaslu dalam forum Tripartit. Meskipun, DKPP merupakan lembaga yang kesekjenannya melekat di Bawaslu. Nur Hidayat Sardini menegaskan bahwa meskipun terbentuk Tripartit, namun masing-masing lembaga tetap dalam koridor kemandirian masing-masing.

Nah dengan Tripartit itu apakah akan meniadakan laporan? Nanti dulu karna ada fakta tidak satu pun yang DKPP hanya karena pertemuan itu mengendorkan pengaduan. Nyatanya dua perkara yang diajukan oleh Bawaslu terhadap KPU di awal-awal itu juga tanda pretensi apapun sangat mandiri. Keterlibatan anggota KPU dan Bawaslu pada saat itu juga tidak ikut campur tangan sama sekali. Rapat Tripartit bersifat koordinatif karena masing-masing lembaga memiliki kemandirian, punya ruang lingkup tugas dan wewenang sendirisendiri. Kalau itu hanaya untuk nego perkara, itu tidak mungkinlah nyatanya kita produktif pada zaman kami.

Dijelaskan pula bahwa hubungan antara KPU, Bawaslu dan DKPP adalah setara. Adapun anggapan umum yang menilai bahwa DKPP memiliki kedudukan lebih tinggi, menurutnya itu hanya efek psikologis dari personal garansi anggota DKPP terhadap kepemiluan terutama ketua DKPP Prof. Jimly Asshiddiqie.

Struktural bertiga koesistensial itu masingmasing lembaga berdiri sendiri kerjanya, ruang lingkup kerjanya, wewenanganya dan kewajiban-kewajibannya sebagaimana undang-undang. Secara struktural, bertiga ini tidak saling membawahi, tidak saling meninggikan satu dan merendahkan yang lain, tidak. Tiga lembaga itu setara, tidak satu pun ketentuan yang saling meninggikan, membawahi satu dengan lainya. Hanya dalam secara fungsional, putusan DKPP final dan mengikat tapi tidak meniadakan struktur. Dengan demikian apakah DKPP lebih tinggi, tidak. Itu saya rasa pertama efek psikologis dari bacaan orang lain, kedua, mungkin saja kata orang angota DKPP ada personal garansi yang tinggi terhadap kepemiluan dan lebih-lebih Prof Jimly, itu harus diakui. Karena Prof Jimly lebih besar dari DKPP. Itu memberi 
ekses social judgment atau yang lebihnya social image yang orang memandang.

Nur Hidayat Sardini tersebut, juga menjelaskan bahwa Tripartit dibentuk DKPP untuk mewujudkan langkah pre-emtifikasi atau pencegahan. Dikutsertakannya KPU dan Bawaslu dalam penyusunan kode etik penyelenggara pemilu dan pedoman beracara diharapkannya dapat mencegah tindakan pelanggaran kode etik. Meskipun terbentuk forum Tripartit, namun Nur Hidayat Sardini menegaskan bahwa masing-masing lembaga memiliki kemandirian yang tidak dapat dipengaruhi.

\section{SIMPULAN}

Penelitian ini menghasilkan model komunikasi konstitutif DKPP periode 20122017 berdasarkan manajemen pengetahuan. Model tersebut menjelaskan bagaimana DKPP telah mengubah pandangan negatif dari stakeholders, yakni DKPP sebagai lembaga penegak kode etik berprinsip pada good governance, terutama prinsip keterbukaan dalam membangun kelembagaan. Selain itu, DKPP melakukan sharing meaning dengan mitra utamanya yakni KPU dan Bawaslu RI untuk mengurangi ambiguitas informasi tentang pentingnya kode etik penyelenggara pemilu dan kedudukan lembaga penegak kode etik penyelenggara pemilu yang diatur dalam UU Nomor 15 Tahun 2011 tentang Penyelenggaran Pemilu. Sehingga memunculkan kesepakatan mengenai Peraturan Bersama KPU, Bawaslu, dan DKPP Nomor 1, 11, 13 Tahun 2012 tentang Kode Etik Penyelenggara Pemilu, dan Peraturan DKPP Nomor 2 Tahun 2012 tentang Pedoman Beracara Kode Etik Penyelenggara Pemilu. DKPP periode 2012-2017 berdasarkan manajemen pengetahuan telah menghilangkan ambiguitas informasi dalam negosiasi keanggotaan, koordinasi aktivitas, pembentukan struktur dan posisi kelembagaan yang merupakan aliran pengorganisasian. Pada aliran negosiasi keanggotaan, pergantian keanggotaan DKPP tidak menjadikannya sebagai persoalan. Prosesnya pergantian juga tidak rumit karena hanya dengan Surat Keputusan dari Ketua DKPP. Kemudian dalam aliran koordinasi aktivitas, pengelolaan DKPP berbasis manajemen pengetahuan telah menciptakan kesepahaman dengan adanya pembagian kerja sesuai dengan kebutuhan lembaga baru yakni penyusunan peraturan DKPP. Selanjutnya, aliran pembentukan struktur DKPP. DKPP berinovasi dalam membentuk struktur formal dan fungsional. Inovasi struktur formal yakni dengan membentuk korwil sebagai pengganti sementara sekretariat DKPP yang sedang proses pembentukan. Kemudian, inovasi struktur fungsional DKPP dengan dibentuknya Tim Pemeriksa Daerah untuk membantu Anggota DKPP melakukan pemeriksaan perkara kode etik penyelenggara pemilu. Terakhir, pada aliran posisi kelembagaan DKPP juga telah dapat membangun hubungan baik dengan mitra utama yakni KPU dan Bawaslu yang mengikatkan diri ke dalam tripartit. Tripartit merupakan bentuk kesadaran terhadap peran dari masing-masing lembaga yang berbeda namun berfungsi satu kesatuan sebagai penyelenggara pemilu.

Peneliti menyarankan agar (1) DKPP secara kontinu menjaga prinsip keterbukaan dalam perkembangan kelembagaannya. (2) DKPP tetap melakukan sharing meaning dengan mitra utama yakni KPU dan Bawaslu (3) DKPP periode 2017-2022 dapat menggunakan model komunikasi konstitutif DKPP Periode 20122017 berdasarkan manajemen pengetahuan sebagai landasan dalam penyesuaian perubahan UU pemilu.

\section{DAFTAR PUSTAKA}

Adi, S. (2016). Variabel pemilu: "free and fair". Jurnal Ide, 28.

Almah, H. (2013). Membangun inovasi di perpustakaan perguruan tinggi melalui konsep $\mathrm{km}$ (knowledge management). Khizanah Al-Hikmah, 91.

Anttiroiko, A. V. (2009). Encyclopedia of information science and technology, volume 1. United States of America: Information Science Reference.

Bungin, B. (2012). Metode penelitian kualitatif. Jakarta: Rajawali Pers.

Bungin, B. (2015). Penelitian kualitatif. Jakarta: Rajawali Pers.

Chakim, M. L. (Juni 2014). Desain institusional dewan kehormatan penyelenggara pemilu (DKPP) sebagai peradilan etik. Jurnal Konstitusi, 402.

Darwis, M. S. (2015). Implementasi kewenangan DKPP pasca putusan Mahkamah Konstitusi 
nomor 115/PHPU.D-XI/2013. Jurnal Konstitusi, 89-90.

Dharmawan, A. (2016, Agustus Selasa). Informasi. RetrievedfromKomisiPemilihan Umum Daerah Istimewa Yogyakarta: http:// diy.kpu.go.id/web/2016/08/22/pentingnyaetika-penyelenggara-pemilu/.

DKPP. (2014). Anotasi peraturan bersama. Jakarta: Pustaka Alvabet.

Griffin, E. (2015). A first look at communication theory edition 9th. New York: McGrawHill.

Gusfa, H. (2016). Pengaruh bullying dalam komunikasi internal terhadap kinerja karyawan di perusahaan wisata. Jurnal Media Kom, 63.

Hardjana, A. (2016). Komunikasi organisasi strategi dan kompetensi. Jakarta: Kompas Media.

Hufron. (2015, November 20). DKPP siap lindungi penyelenggara pemilu. Diambil dari Siaran Indonesia: http://www. siaranindonesia.com/baca/20151120/dkppsiap-lindungi-penyelenggara-pemilu.html.

Iskandar. (2009). Metode penelitian pendidikan dan sosial. Jakarta: GP Press.

McPhee, R. D., \& Zaug, P. (2000). The communicative constitution of organizations: a framework for explanation. The Electronic Journal of Communication, $1-2$.

Moleong, L. J. (2001). Metodologi penelitian kualitatif. Bandung: Remaja Rosdakarya.

Moleong, L. J. (2006). Metodologi penelitian kualitatif. Bandung: Remaja Rosdakarya.

Murti, R. A., Lestari, M. T., \& Ali, D. S. (2017). Komunikasi organisasi PT. PLN (PERSERO) area Bandung dalam kegiatan code of conduct. Jurnal Kajian Komunikasi, 5(2), 210-221. DOI: https:// doi.org/10.24198/jkk.v5i2.8487

Prabowo, H. (2010). Knowledge management di perguruan tinggi. Binus Business Review, 407.

Prabowo, T. T. (2016). Implementasi manajemen pengetahuan di perpustakaan UIN Sunan Kalijaga Yogyakarta. Jurnal Kajian Informasi \& Perpustakaan, 163.
Programme, United Nations Development. (2011). Governance principles, institutional capacity and quality. New York: Bureau for Development Policy One United Nations Plaza.

Purwasih, N., \& Sensuse, D. I. (2014). Pengembangan strategi manajemen pengetahuan untuk mendukung pelaksanaan reformasi birokrasi: sebuah studi kasus di Kementerian Perindustrian. Journal of Information Systems. 10(1). 53-62. DOI: https://doi.org/10.21609/jsi. v10i1.378.

Putnam, L. L., \& Nicotera, A. M. (2009). Building Theories of Organization The Constitutive Role of Communication. New York: Routledge.

Rachmat, K. (2008). Teknik Praktis Riset Komunikasi. Jakarta: Kencana Prenada Media Group.

Sardini, N. H. (2015). Mekanisme Penyelesaian Pelanggaran Kode Etik Penyelenggara Pemilu. Jakarta: Lembaga Pengembangan Pendidikan Anak Bangsa (LP2AB).

Siregar, A. R. (2005). Manajemen pengetahuan perspektif pustakawan. Jurnal Studi Perpustakaan dan Informasi, 1(1) 1-6. Diakses dari http://puslit2.petra. ac.id/ejournal/index.php/pus/article/ view/17239/17192.

Syarwani, A. (2017, Juni). Aktivitas dewan kehormatan penyelenggara pemilu. Diakses dari http://dkpp.go.id/index. php $\mathrm{a}=$ detilberita\&id $=2557$.

Wahid, A. (2016). Kode etik peserta pemilu sebagai penguatan demokrasi di Indonesia. Jurnal Etika \& Pemilu, 12.

West, R., \& Turner, L. H. (2007). Pengantar teori komunikasi analisis dan aplikasi ed 3. Jakarta: Salemba Humanika.

Widadi, A. (2013, Juli). Integritas pemilu dan setahun dkpp. Diakses dari detik.com: https://news.detik.com/kolom/2288941/ integritas-pemilu-dan-setahun-dkpp.

Wihdatiningtyas, E. (2017, Oktober). (Irmawanti, Interviewer).

Yin, R. K. (2015). Studi kasus desain \& metode. Depok: Raja Grafindo. 